\title{
Effectiveness of a Long-Term Training Programme for Teachers in Attention-Deficit/Hyperactivity Disorder on Knowledge and Self-Efficacy
}

\author{
Sonia Jarque Fernández ${ }^{1,+}$, Laura Amado Luz ${ }^{2,+}$, Marta Oporto Alonso ${ }^{2, *(D)}$ and Marina Fernández-Andújar ${ }^{2, *}$ \\ 1 Facultat de Psicología, Universitat de Barcelona, 08035 Barcelona, Spain; soniajarque@ub.edu \\ 2 Facultad de Psicología, Universitat Abat Oliba CEU, CEU Universities, 08022 Barcelona, Spain; \\ lamadol@uao.es \\ * Correspondence: moportoa@uao.es (M.O.A.); mfernandezan@uao.es (M.F.-A.); \\ Tel.: +34-932-540-900 (M.O.A. \& M.F.-A.) \\ + Both authors are first authors.
}

Citation: Jarque Fernández, S.; Amado Luz, L.; Oporto Alonso, M.; Fernández-Andújar, M. Effectiveness of a Long-Term Training Programme for Teachers in Attention-Deficit/

Hyperactivity Disorder on

Knowledge and Self-Efficacy. Mathematics 2021, 9, 1414. https:/ / doi.org/10.3390/math9121414

\section{Academic Editors:}

Antonio Rodríguez Fuentes and José Luis Gallego Ortega

Received: 6 May 2021

Accepted: 15 June 2021

Published: 18 June 2021

Publisher's Note: MDPI stays neutra with regard to jurisdictional claims in published maps and institutional affiliations.

Copyright: (c) 2021 by the authors. Licensee MDPI, Basel, Switzerland. This article is an open access article distributed under the terms and conditions of the Creative Commons Attribution (CC BY) license (https:// creativecommons.org/licenses/by/ $4.0 /)$.

\begin{abstract}
The active participation of teachers in the process of diagnosis and intervention of AttentionDeficit/Hyperactivity Disorder (ADHD) is relevant to helping mitigate future problems in children with ADHD. In training programmes, teachers usually implement strategies to improve the child's functioning after participating in an ADHD management-training programme. However, they receive little psycho-educational training and coaching and have low-to-moderate levels of knowledge of the disorder, mostly in terms of training in classroom management strategies. This study analyses the effectiveness of training in increasing knowledge and perceived self-efficacy with regard to ADHD in 40 primary school teachers. Twenty of these teachers participated in a long-term psycho-educational training programme on the management of ADHD (intervention multimodal group), while the other $20 \mathrm{did}$ not (control group). The results of the post-treatment phase revealed statistically significant differences between the two groups of teachers with regard to their knowledge $(Z=-5.427 ; p=0.000$; $\mathrm{d}=0.89)$ and perceived self-efficacy $(Z=-5.150 ; p=0.000 ; \mathrm{d}=0.79)$, in favour of the participants who had received training. Our findings have important implications for the design of training programmes for teachers in the management of ADHD in the classroom.
\end{abstract}

Keywords: knowledge of ADHD; teacher training; ADHD children; treatment

\section{Introduction}

Attention-Deficit/Hyperactivity Disorder (ADHD), one of the most common mental disorders affecting children and adults, is a neurodevelopmental disorder characterised by inattention, hyperactivity, and impulsivity [1], which negatively interfere in the functioning of affected people in their daily developmental routines [2,3]. Often, associations with other disorders occur (for example with learning disabilities) [4,5]. Recent studies show the negative impact of ADHD on mathematics learning, as attention plays a relevant role in mathematical ability [6]. The World Federation of ADHD indicate that it is more common in men and occurs in $5.9 \%$ of young people and $2.5 \%$ of adults, according to studies carried out in regions such as Europe, Scandinavia, Australia, Asia, the Middle East, South America, and North America [7]. The worldwide prevalence rates are estimated to be around $5 \%$, and among the school population the prevalence of ADHD ranges from $1 \%$ to $20 \%$ [8,9], with a significant rise in the number of cases $(24 \%)$ being reported between 2001 and 2010 [1,10]. In Spanish-speaking countries such as Spain, studies indicate prevalence ranges from $2-6 \%$ [11,12], with an average prevalence of $6.8 \%$ [13], and $5.4 \%$ in preschool-aged children [14].

Early detection and treatment of children with ADHD is important as it can help mitigate future problems that can arise over time. Empirically validated ADHD treatments 
include stimulant medication, psychosocial intervention or a combination of the two [15-18]. Pharmacological treatments (stimulant medication), although shown to be effective, fail to maintain their long-term benefits, which has led to the inclusion of multimodal treatments (a combination of medication and psychosocial treatment) with long-term effects in ADHD treatment guidelines [19]. In psychosocial interventions, the parents and/or teachers usually implement strategies to improve the child's functioning after participating in an ADHD management-training programme. Along this line, various studies have highlighted the importance of the active participation of teachers in the process of diagnosis and intervention of ADHD [20-24]. Teachers spend a lot of time with their students, and their experience allows them to compare their own conduct with that of a reference group. However, for this participation to be fruitful, it is important for teachers to have a basic understanding of the disorder, for several reasons [25]: 1. ADHD is one of the most prevalent neurodevelopmental disorders in the school population; 2 . Teachers identify children with ADHD more often than parents or doctors [26]; 3. The behavioural assessments of the pupil that the teacher carries out, along with the parents' assessments and neuropsychological tests, are necessary to establish a diagnosis of ADHD [21]; 4. Teachers play an active role in the implementation of interventions within the school environment [21,22]; 5 . Teachers have frequent contact with pupils' families [20,23]; 6 . Teachers with a greater knowledge of ADHD behave more favourably towards affected children [20,27-30]; 7. Teachers with a greater knowledge of ADHD also have higher levels of perceived self-efficacy [31-34] and less ambivalent behaviours towards these children [35]: 8. Teachers with a greater knowledge of ADHD implement educational interventions more effectively [23].

Nevertheless, despite the benefits that may be gained from teachers trained in the management of ADHD in the classroom, current research suggests that they receive little psycho-educational training and coaching in this respect in both initial and continuing training $[24,28,36,37]$ and have low-to-moderate levels of knowledge of the disorder, mostly in terms of training in classroom management strategies [38]. Other authors point out that teachers' sources of learning about ADHD are usually other teachers, some training offered in schools, and their own personal experience [39]. Teachers also recognise that helping students with ADHD is a complex demand, and they often experience feelings of guilt in relation to interactions with students, implementing strategies by trial and error or strategies known through nonformal means. In this regard, questionnaire-based studies obtained correct answers ranging from $17.2 \%$ [34] to $82.8 \%$ [27]. More specifically, studies that have employed the Knowledge of Attention Deficit Disorders Scale (KADDS) [31] observed varying percentages in correct answers, ranging from 15\% to $62 \%$ [24], although most obtained correct answer percentages of around 50\% [21,31,40-45]. Some studies demonstrated that teachers had greater knowledge of the diagnostic symptoms of ADHD than other subjects, such as for instance treatment, probably because it is the most commonly observed feature in the classroom $[21,24,28,31,33,34,46,47]$.

One factor that has been found to be associated with teachers' levels of ADHD knowledge, even cross-culturally, is psychoeducational training in ADHD management $[21,24,33,41,48-53]$. Thus, it has been shown that even brief training of primary school teachers in this area can increase their knowledge and perceived self-efficacy in the management of ADHD [53]. In the same vein, some studies have also found an association between ADHD training and teachers' perceived levels of self-efficacy in managing ADHD in the classroom $[49,52,53]$. For all the above reasons, we consider it relevant that teachers receive optimal psychoeducational training in the management of ADHD. The aims of this study are: to analyse the potential impact of a training programme for teachers in ADHD on their levels of knowledge of the disorder and their level of perceived self-efficacy. To this end, we compared two groups of teachers: one that participated in a training course and another that did not. On the basis of these aims, we hypothesised that statistically significant differences would be obtained between the groups in the posttreatment phase, with the multimodal intervention group showing a superior increase in their knowledge and perceived self-efficacy. 


\section{Materials and Methods}

A quasi-experimental mixed design (intra- and intergroup) was carried out in which pre- and post-treatment data were collected [54,55]. 40 teachers of 20 children diagnosed with ADHD (two teachers per child) took part in the study. The characteristics of the participants can be seen in Tables 1 and 2.

Table 1. Sociodemographic characteristics of the sample of children with AttentionDeficit/Hyperactivity Disorder (ADHD).

\begin{tabular}{lll}
\hline \multicolumn{1}{c}{ Characteristics } & \multicolumn{1}{c}{ Control Group } & \multicolumn{1}{c}{$\begin{array}{c}\text { Multimodal } \\
\text { Group }\end{array}$} \\
\hline Age & & \\
7 years & $3(30 \%)$ & $3(30 \%)$ \\
8 years & $4(40 \%)$ & $4(40 \%)$ \\
9 years & $3(30 \%)$ & $3(30 \%)$ \\
Mean age & 7.6 & 7.8 \\
Sex & & \\
Male & $8(80 \%)$ & $9(90 \%)$ \\
Female & $2(20 \%)$ & $1(10 \%)$ \\
\hline
\end{tabular}

Table 2. Sociodemographic characteristics of the sample of teachers.

\begin{tabular}{lll}
\hline \multicolumn{1}{c}{ Characteristics } & \multicolumn{1}{c}{ Control Group } & \multicolumn{1}{c}{$\begin{array}{c}\text { Multimodal } \\
\text { Group }\end{array}$} \\
\hline Mean age & 40.3 & 38.4 \\
\hline $\begin{array}{l}\text { Sex } \\
\text { Males }\end{array}$ & $4(20 \%)$ & $7(35 \%)$ \\
Females & $16(80 \%)$ & $13(65 \%)$ \\
\hline $\begin{array}{l}\text { Experience as a teacher } \\
\text { (mean) }\end{array}$ & 23.5 & 19.1 \\
\hline $\begin{array}{l}\text { Previous experience with } \\
\text { children with Attention- }\end{array}$ & $9(45 \%)$ & $12(60 \%)$ \\
$\begin{array}{l}\text { Deficit/Hyperactivity } \\
\text { Disorder (ADHD) }\end{array}$ & & $1(5 \%)$ \\
\hline $\begin{array}{l}\text { Previous attendance of ADHD } \\
\text { courses }\end{array}$ & 0 & \\
\hline
\end{tabular}

All subjects gave their informed consent for inclusion before they participated in the study. The study was conducted in accordance with the Declaration of Helsinki, and the protocol was approved by the Ethics Committee of Abat Oliba University, CEU Universities (EDU2012-31402).

All children were taking stimulant medication prescribed by their paediatricians at the start of the study. Half of the teachers of these children also participated in psychoeducational training (multimodal intervention group), while the other half of the teachers did not receive training (wait-list control group, medication only). Once the study was completed, at the beginning of the following academic year, the teachers in the control group were offered the opportunity to participate in a training course on ADHD management.

\subsection{Sample of Children}

The 10 children in the control group were chosen from three private schools in Barcelona after obtaining the parents' informed consent. The children ranged from 7 to 9 years old, with a clear predominance of boys over girls. All the children were diagnosed with combined subtype ADHD.

The 10 children in the multimodal treatment group came from a private school in Barcelona, and their parents gave their informed consent for their children to participate in 
the study. The ages of this group ranged from 7 to 9 years, with a clear predominance of boys over girls. Eight were diagnosed with combined subtype ADHD, one with ADHD subtype inattentive, and one with ADHD subtype hyperactive-impulsive.

\subsection{Sample of Teachers}

40 teachers took part in the study. They were assigned to the multimodal intervention group $(\mathrm{N}=20)$ or the control group $(\mathrm{N}=20)$. They were all primary school teachers. The average age of the teachers in the control group was 40.3 years, with a clear predominance of women over men. These teachers had an average previous teaching experience of 23.5 years, and almost half of them had experience teaching students with ADHD. None of these teachers had previously attended any specialised ADHD course.

The average age of the multimodal treatment group was 38.4 years. In this group too there was a clear predominance of women over men. These teachers had an average teaching experience of 19.1 years, and just over half of them had had some experience of teaching students with ADHD. Only one of these had attended a brief previous course on ADHD outside of this project.

\subsection{Measurements}

This study employed the Spanish version of KADDS [21,31,32] both before and after the implementation of the intervention. It consists of a questionnaire with 36 items with three choices (true, false, don't know). The questions were grouped into three subscales: (a) General information on the nature, causes, and consequences of ADHD (15 items);

(b) Symptoms/Diagnosis (nine items); and (c) Treatment (12 items).

Studies of other samples have shown that the Spanish version of the questionnaire has adequate reliability indices $[21,32]$, specifically an elevated alpha coefficient over the total scale (0.89), a high correlation between subscales (range $r=0.62-0.69 ; \mathrm{r}=0.50-0.55$; $r=0.48-0.63$ ), and of each subscale with the total score (range $r=0.79-0.87 ; r=0.85-0.90$; $r=0.78-0.87$ ).

A 7-point Likert scale was used to evaluate teachers' levels of perceived self-efficacy with regard to successfully teaching these children. The participants answered the following question: "How effectively do you think you can teach a pupil with ADHD? Answer bearing in mind that 1 is the lowest (not trained to effectively teach a child with ADHD) and 7 is the highest (fully trained)".

\subsection{Procedure}

The teacher training programme took place in the teacher's own school between October and June every two weeks. In total, teachers attended 17 sessions of two hours each. The training sessions were divided into eight thematic blocks [56] (Figure 1) based on the manual of Miranda et al. (1999) and other ADHD intervention programmes [57,58]: 1. General knowledge of ADHD; 2. Intervention modes in ADHD; 3. Behaviour improvement strategies; 4 . Teaching management strategies; 5 . Adaptations in teaching activities; 6. Stress management strategies; 7. Communication skills; 8 . End-of-course summary.

This training programme and the way in which it was implemented have a number of characteristics that differentiate it from the training courses usually carried out in this field. Firstly, it lasts for an extended period of time, a full academic year, in order to provide teachers with advice in parallel with the circumstances and problems that arise in the class. Secondly, the programme includes sessions on stress management and emotional management techniques for teachers, as well as on improving their communication skills with families. Finally, the coach, one of the researchers of the study, is a specialist in the management of ADHD and has a long history of teacher training in this area. Teacher attendance at the course was very high (98\%), possibly because it was held at the school where they worked and at the end of the school day. 


\begin{tabular}{|c|c|}
\hline Month & Contents \\
\hline September & $\begin{array}{l}\text { Presentation and organisation (session } 0 \text { ): } \\
\text { - Schedule. } \\
\text { - Completion of informed consent forms and questionnaires. }\end{array}$ \\
\hline October & $\begin{array}{l}\text { I INTRODUCE MYSELF: My student and I (sessions } 1 \text { and 2): } \\
\text { - Description of pupils with ADHD. } \\
\text { - Mutual recommendation of ADHD bibliography for teachers. }\end{array}$ \\
\hline November & $\begin{array}{l}\text { I KNOW AND I UNDERSTAND: Knowledge of ADHD (sessions 3-4): } \\
\text { - Exchange of experiences through lectures on ADHD. }\end{array}$ \\
\hline December & $\begin{array}{l}\text { WHAT WE CAN DO: Intervention procedures for ADHD (session 5): } \\
\text { - Analysis of empirically validated intervention procedures. }\end{array}$ \\
\hline $\begin{array}{l}\text { January } \\
\text { February }\end{array}$ & $\begin{array}{l}\text { I POSITIVELY EVALUATE THE CHILD. THE CHILD SELF-EVALUATES AND REINFORCES (sessions 6,7, 8): } \\
\text { - Training in behavioral modification and cognitive-behavioral techniques. }\end{array}$ \\
\hline March & $\begin{array}{l}\text { I ADAPT THE CLASSROOM AND ACTIVITIES (sessions 9-12): } \\
\text { - Strategies for education management. } \\
\text { - Learning teaching and classroom adaptations to favor attention and behavior. }\end{array}$ \\
\hline April & $\begin{array}{l}\text { WE BUILD BRIDGES (sessions } 13 \text { and } 14 \text { ): } \\
\text { - Strategies to improve skills in communicating with families. }\end{array}$ \\
\hline May & $\begin{array}{l}\text { I IMPROVE MY SELF CONTROL (sessions } 15 \text { and 16): } \\
\text { - Training in relaxation techniques for teachers in conflict situations. }\end{array}$ \\
\hline June & $\begin{array}{l}\text { FAREWELL: what I take with me (session 17): } \\
\text { - Highlight the progress observed in the teachers and their pupils. } \\
\text { - Completion of questionnaires. }\end{array}$ \\
\hline
\end{tabular}

Figure 1. Schedule and contents of a teacher intervention programme. Note: ADHD = Attention-Deficit/Hyperactivity Disorder.

\subsection{Statistical Analysis}

For the statistical analysis, we used the software programme SPSS-26.0 with a confidence interval equal to or less than 0.05 .

Firstly, descriptive statistics were used to analyse the socio-demographic characteristics of the participants, and the averages and deviations typical of diverse measurements. Likewise, in order to carry out the intra- and intergroup comparisons, nonparametric tests were applied, as the parametricity conditions were not met. A Wilcoxon test was used to compare related samples (intragroup) between the pre- and post-treatment phases. Comparisons were also made between the control group and multimodal treatment group, 
both in the pre- and post-treatment phase, by applying a Mann Whitney U test. We also calculated the effect size ( $\mathrm{d}$ of Cohen) on measures that were statistically significant.

\section{Results}

\subsection{Knowledge and Perceived Self-Efficacy}

\subsubsection{Control Group}

In both the pre-test and post-test phases, teachers who did not receive the ADHD training answered a moderate percentage of the questions correctly (around 50\%) (Table 3). The greatest number of correct answers was obtained in the Symptoms/Diagnosis subscale, followed by Treatment, and finally General Information.

Table 3. Intragroup comparisons on Attention-Deficit/Hyperactivity Disorder (ADHD) knowledge and perceived self-efficacy in teachers of the control group.

\begin{tabular}{|c|c|c|c|c|}
\hline Knowledge & Pre Treatment & Post Treatment & $Z$ & $p$ \\
\hline Total Scale & $\begin{array}{l}\text { M } 54.6 \\
\text { SD } 5.20\end{array}$ & $\begin{array}{l}\text { M } 53.5 \\
\text { SD } 6.04\end{array}$ & -1.080 & 0.280 \\
\hline $\begin{array}{l}\text { General } \\
\text { Information }\end{array}$ & $\begin{array}{l}\text { M } 43.30 \\
\text { SD } 9.55\end{array}$ & $\begin{array}{l}\text { M } 43.96 \\
\text { SD } 9.77\end{array}$ & -0.312 & 0.755 \\
\hline $\begin{array}{l}\text { Symptoms/ } \\
\text { Diagnosis }\end{array}$ & $\begin{array}{l}\text { M } 64.38 \\
\text { SD 12.26 }\end{array}$ & $\begin{array}{l}\text { M } 63.27 \\
\text { SD 11.44 }\end{array}$ & -0.933 & 0.351 \\
\hline Treatment & $\begin{array}{l}\text { M } 56.22 \\
\text { SD } 10.77\end{array}$ & $\begin{array}{l}\text { M } 53.31 \\
\text { SD } 9.51\end{array}$ & -1.381 & 0.167 \\
\hline $\begin{array}{l}\text { Perceived } \\
\text { self-efficacy }\end{array}$ & $\begin{array}{l}\text { M } 2.6 \\
\text { SD } 0.88\end{array}$ & $\begin{array}{l}\text { M } 2.3 \\
\text { SD } 0.92\end{array}$ & -2.49 & $0.014^{*}$ \\
\hline
\end{tabular}

Note: $\mathrm{M}=$ mean; $\mathrm{SD}=$ Standard Deviation. ${ }^{*} p<0.05$.

The level of knowledge of these teachers about ADHD did not increase in the post-test phase, neither in the overall scale nor in the subscales (Table 3). The data also reveal that these teachers experienced a significant reduction in their level of perceived self-efficacy (in the post-test phase) with regard to successfully teaching their students with ADHD (Table 3).

\subsubsection{Multimodal Intervention Group}

Our data shows that before participating in the intervention, teachers answered half the questions correctly and that the greatest number of correct answers was obtained in the Symptoms/Diagnosis subscale, followed by Treatment, and finally General Information.

After the intervention, teachers correctly answered an average of $77.30 \%$ of the questions. The greatest number of correct answers in the post-test was obtained in the Treatment subscale, followed by the Symptoms/Diagnosis subscale, and finally General Information. The data indicate that after treatment, the increase in the teachers' level of knowledge of ADHD is significant, both in the total score and in the three subscales (Table 4).

Additionally, the teachers who participated in the training programme significantly increased their level of perceived self-efficacy in successfully teaching their students with ADHD after the intervention (Table 4).

\subsubsection{Comparison Between Both Groups}

While in the pretreatment phase, both groups had similar levels of knowledge about ADHD, in the post-treatment phase, the teachers from the multimodal treatment group had significantly greater knowledge, both in the overall scale and in the three subscales (Table 5). The level of perceived self-efficacy was similar in both groups in the pre-test phase. However, after treatment, the level of perceived self-efficacy of the teachers from the multimodal treatment group increased above that of teachers from the control group, with the differences being statistically significant (Table 5). 
Table 4. Intragroup comparisons on Attention-Deficit/Hyperactivity Disorder (ADHD) knowledge and perceived self-efficacy in teachers of the multimodal treatment group.

\begin{tabular}{|c|c|c|c|c|c|}
\hline Knowledge & Pre Treatment & Post Treatment & $Z$ & $p$ & d \\
\hline Total Scale & $\begin{array}{l}\text { M } 53.6 \\
\text { SD 5.71 }\end{array}$ & $\begin{array}{l}\text { M } 77.30 \\
\text { SD } 5.57\end{array}$ & -3.927 & $0.000 * *$ & 0.90 \\
\hline $\begin{array}{c}\text { General } \\
\text { Information }\end{array}$ & $\begin{array}{l}\text { M } 43.30 \\
\text { SD } 10.26\end{array}$ & $\begin{array}{l}\text { M } 73.96 \\
\text { SD } 8.34\end{array}$ & -3.932 & $0.000^{* *}$ & 0.85 \\
\hline $\begin{array}{c}\text { Symptoms/ } \\
\text { Diagnosis }\end{array}$ & $\begin{array}{l}\text { M } 60.49 \\
\text { SD } 14.33\end{array}$ & $\begin{array}{l}\text { M } 75.48 \\
\text { SD } 11.73\end{array}$ & -2.888 & $0.004^{* *}$ & 0.51 \\
\hline Treatment & $\begin{array}{l}\text { M } 57.05 \\
\text { SD } 9.84\end{array}$ & $\begin{array}{l}\text { M } 82.47 \\
\text { SD } 10.07\end{array}$ & -3.835 & $0.000^{* *}$ & 0.79 \\
\hline $\begin{array}{c}\text { Perceived } \\
\text { self-efficacy }\end{array}$ & $\begin{array}{l}\text { M } 2.35 \\
\text { SD } 0.93\end{array}$ & $\begin{array}{l}\text { M } 4.75 \\
\text { SD } 0.96\end{array}$ & -4.008 & $0.000^{* *}$ & 0.78 \\
\hline
\end{tabular}

Table 5. Intergroup comparisons on Attention-Deficit/Hyperactivity Disorder (ADHD) knowledge and perceived self-efficacy between the control group and multimodal group in the post-treatment phase.

\begin{tabular}{|c|c|c|c|c|c|}
\hline Knowledge & Control Group & Multimodal Group & $Z$ & $p$ & $d$ \\
\hline Total Scale & $\begin{array}{l}\text { M } 53.5 \\
\text { SD } 6.04\end{array}$ & $\begin{array}{l}\text { M } 77.30 \\
\text { SD 5.57 }\end{array}$ & -5.414 & $0.000^{* *}$ & 0.89 \\
\hline $\begin{array}{c}\text { General } \\
\text { Information }\end{array}$ & $\begin{array}{l}\text { M } 43.96 \\
\text { SD } 9.77\end{array}$ & $\begin{array}{l}\text { M } 73.96 \\
\text { SD } 8.34\end{array}$ & -5.416 & $0.000^{* *}$ & 0.85 \\
\hline $\begin{array}{l}\text { Symptoms / } \\
\text { Diagnosis }\end{array}$ & $\begin{array}{c}\text { M } 63.27 \\
\text { SD 11.44 }\end{array}$ & $\begin{array}{c}\text { M } 75.48 \\
\text { SD } 11.73\end{array}$ & -2.871 & $0.004^{* *}$ & 0.47 \\
\hline Treatment & $\begin{array}{l}\text { M } 53.31 \\
\text { SD } 9.51\end{array}$ & $\begin{array}{l}\text { M } 82.47 \\
\text { SD } 10.07\end{array}$ & -5.273 & $0.000^{* *}$ & 0.83 \\
\hline $\begin{array}{l}\text { Perceived } \\
\text { self-efficacy }\end{array}$ & $\begin{array}{c}\text { M } 2.3 \\
\text { SD } 0.92\end{array}$ & $\begin{array}{l}\text { M } 4.75 \\
\text { SD } 0.96\end{array}$ & -5.150 & $0.000 * *$ & 0.79 \\
\hline
\end{tabular}

\section{Discussion and Conclusions}

One of the main aims of this study was to analyse the potential impact of a training programme for teachers in ADHD on their levels of knowledge of the disorder. In this regard, we found that the two groups of teachers had a moderate level of knowledge (53\%) prior to taking part in the study. This result is similar to those observed in previous studies that employed the same questionnaire: 42.65\% [21]; 45.8\% [40]; 47.8\% [31]; 48.9\% [41]; $45 \%$ [42]; ranging between 15-62\% [24]; 49\% [43]; 48\% [44]; and 55.2\% [45].

After the training, we observed that the teachers who did not participate in the training programme did not increase their level of knowledge of ADHD. Nevertheless, there was a significant increase in the level of knowledge of the teachers who took part in the training course, both in the total scale and the subscales, with the level of global knowledge rising to $77.30 \%$. The subscale to receive the best score was the Treatment subscale, followed by the Symptoms/Diagnosis and General Information subscales, probably because the training course received by the teachers dedicated several sessions to the intervention modes and the conceptualisation of ADHD.

These results are consistent with those obtained in previous studies, which also observed a significant increase in teachers' knowledge of ADHD after participating in a training course in ADHD management [38,41,51-53,59]. In conclusion, the training of teachers of children with ADHD in instructional strategies to improve the teachinglearning process - especially in mathematics-increases both the level of knowledge about the disorder as well as the perceived self-efficacy in teaching ADHD students [60]. The second aim of our study consisted in analysing the possible effects of the teacher-training programme on the teachers' level of perceived self-efficacy. In the post-treatment phase, the level of perceived self-efficacy with regard to successfully teaching students with ADHD 
decreased significantly in the control group. By contrast, a significant increase in perceived self-efficacy was observed in the teachers who attended the training course.

These results can be understood in light of what we mean by self-efficacy [61] and the factors that can increase it. Teachers who neither received any ADHD-specific training nor received assistance from a support group/specialised professional during the academic year possibly did not have access to any model that provided them with an opportunity for vicarious learning. Moreover, they may neither have been in a position to be able to review their past and present experiences nor received feedback on their conduct with respect to students with ADHD over the school year.

However, in the teachers of the multimodal intervention group, participation in the psycho-educational group may have increased the main factors affecting an individual's perceived self-efficacy. Thus, the training allowed teachers to reflect on their previous teaching experience as well as being an invaluable source of vicarious learning. Moreover, it provided them with positive feedback after applying the techniques they had learnt during the course in their own classrooms.

This finding is consistent with the results of other studies that confirmed the existence of a positive relation between specific training for teachers in ADHD and their beliefs in their capacity to successfully teach students with ADHD [21,24,32,49,52,62-67].

In conclusion, our study confirms that training teachers in the management of ADHD in the classroom can bring about a significant increase in their level of knowledge and perceived self-efficacy, hence the importance of promoting the implementation of these training courses for primary education teachers, as has been done in this study.

Nevertheless, our study has some limitations that should be taken into account so that they can be avoided in future studies on teaching students with ADHD. Firstly, the small size of the subsamples used led us to employ nonparametric tests that could have a lower discriminatory power. A further limitation was that we did not have data from any follow-up assessments that could have allowed us to determine the effectiveness of a long-term intervention.

Lastly, teachers' perceived self-efficacy could have been measured using a more objective validated instrument, not just the Likert scale.

Despite these limitations, our study sheds light on the benefits of designing and implementing training programmes for teachers in the management of ADHD with the characteristics of the programme presented (long duration, emotional management sessions, and communication skills with families), with the ultimate aim of rising to the challenge of successfully teaching students with ADHD.

Author Contributions: Conceptualization, S.J.F., L.A.L., M.O.A. and M.F.-A.; Methodology, S.J.F., L.A.L., M.O.A. and M.F.-A.; Formal analysis, S.J.F., L.A.L., M.O.A. and M.F.-A.; Investigation, S.J.F., L.A.L., M.O.A. and M.F.-A.; Training, L.A.L.; Resources, S.J.F., L.A.L., M.O.A. and M.F.-A.; Data curation, S.J.F., L.A.L., M.O.A. and M.F.-A.; Writing-Original Draft Preparation, S.J.F., L.A.L., M.O.A. and M.F.-A.; Writing-Review \& Editing, S.J.F., L.A.L., M.O.A. and M.F.-A.; Visualization, S.J.F., L.A.L., M.O.A. and M.F.-A.; Supervision, S.J.F., L.A.L., M.O.A. and M.F.-A.; Project administration, S.J.F., L.A.L.; Funding Acquisition, S.J.F., L.A.L. All authors have read and agreed to the published version of the manuscript.

Funding: This research was funded by Plan Nacional I+D+I del Ministerio de Economía y Competitividad, Gobierno de España, grant number EDU2012-31402.

Institutional Review Board Statement: This study was conducted in accordance with the Declaration of Helsinki, and the protocol was approved by the Ethics Committee of Abat Oliba University, CEU Universities (protocol code 004, 17 March 2021).

Informed Consent Statement: Informed consent was obtained from all subjects involved in the study.

Data Availability Statement: Not applicable.

Conflicts of Interest: The authors declared no potential conflicts of interest with respect to the research, authorship, and/or publication of this article. 


\section{References}

1. American Psychiatric Association (APA). Diagnostic and Statistical Manual of Mental Disorders, 5th ed.; American Psychiatric Association: Washington, DC, USA, 2013; pp. 31-87.

2. Cabral, M.; Liu, S.; Soares, N. Attention-deficit/hyperactivity disorder: Diagnostic criteria, epidemiology, risk factors and evaluation in youth. Transl. Pediatr. 2020, 9 (Suppl. 1), S104-S113. [CrossRef]

3. Thapar, A.; Cooper, M. Attention deficit hyperactivity disorder. Lancet 2016, 387, 1240-1250. [CrossRef]

4. Sexton, C.C.; Gelhorn, H.L.; Bell, J.A.; Classi, P.M. The co-occurrence of reading disorder and ADHD: Epidemiology, treatment, psychosocial impact, and economic burden. J. Learn. Disabil. 2012, 45, 538-564. [CrossRef]

5. von Wirth, E.; Kujath, K.; Ostrowski, L.; Settegast, E.; Rosarius, S.; Döpfner, M.; Schwenk, C.; Kuhn, J.T. The co-occurrence of Attention-Deficit/Hyperactivity Disorder and mathematical difficulties: An investigation of the role of basic numerical skills. Res. Dev. Disabil. 2021, 112, 103881. [CrossRef]

6. Tosto, M.G.; Momi, S.K.; Asherson, P.; Malki, K. A systematic review of attention deficit hyperactivity disorder (ADHD) and mathematical ability: Current findings and future implications. BMC Med. 2015, 13, 1-14. [CrossRef]

7. Faraone, S.V.; Banaschewski, T.; Coghill, D.; Zheng, Y.; Biederman, J.; Bellgrove, M.A.; Newcorn, J.H.; Gignac, M.; Al Saud, N.M.; Wang, Y.; et al. The world federation of ADHD international consensus statement: 208 evidence-based conclusions about the disorder. Neurosci. Biobehav. Rev. 2021, in press. [CrossRef]

8. Polanczyk, G.; De Lima, M.S.; Horta, B.L.; Biederman, J.; Rohde, L.A. The worldwide prevalence of ADHD: A systematic review and metaregression analysis. Am. J. Psychiatry 2007, 164, 942-948. [CrossRef] [PubMed]

9. Polanczyk, G.V.; Willcutt, E.G.; Salum, G.A.; Kieling, C.; Rohde, L.A. ADHD prevalence estimates across three decades: An updated systematic review and meta-regression analysis. Int. J. Epidemiol. 2014, 43, 434-442. [CrossRef] [PubMed]

10. Getahun, D.; Jacobsen, S.J.; Fasset, M.J. Recent trends in childhood Attention-Deficit/Hyperactivity Disorder. JAMA Pediatr. 2013, 167, 282-288. [CrossRef] [PubMed]

11. Criado-Álvarez, J.J.; Romo-Barrientos, C. Variabilidad y tendencias en el consumo de metilfenidato en España. Estimación de la prevalencia del trastorno por déficit de atención con hiperactividad. Rev. Neurol. 2003, 37, 806-810. [CrossRef] [PubMed]

12. Fayyad, J.; Sampson, N.A.; Hwang, I.; Adamowski, T.; Aguilar-Gaxiola, S.; Al-Hamzawi, A.; Andrade, L.H.S.G.; Borges, G.; de Girolamo, G.; WHO World Mental Health Survey Collaborators; et al. The descriptive epidemiology of DSM-IV adult ADHD in the world health organization world mental health surveys. ADHD Atten. Deficit Hyperact. Disord. 2017, 9, 47-65. [CrossRef]

13. Catalá-López, F.; Peiró, S.; Ridao, M.; Sanfélix-Gimeno, G.; Gènova-Maleras, R.; Catalá, M.A. Prevalence of attention deficit hyperactivity disorder among children and adolescents in Spain: A systematic review and meta-analysis of epidemiological studies. BMC Psychiatry 2012, 12, 168-181. [CrossRef] [PubMed]

14. Canals, J.; Morales-Hidalgo, P.; Jané, M.C.; Domènech, E. ADHD prevalence in Spanish Preschoolers: Comorbidity, Sociodemographic Factors, and Functional Consequences. J. Atten. Disord. 2018, 22, 143-153. [CrossRef] [PubMed]

15. Coghill, D.R.; Seth, S.; Pedroso, S.; Usala, T.; Currie, J.; Gagliano, A. Effects of methylphenidate on cognitive functions in children and adolescents with Attention-Deficit/Hyperactivity Disorder: Evidence from a systematic review and a meta-analysis. Biol. Psychiatry 2013, 76, 603-615. [CrossRef] [PubMed]

16. Miranda, A.; Presentación, M.J.; Siegenthaler, R.; Jara, P. Effects of a psychosocial intervention on the executive functioning in children with ADHD. J. Learn. Disabil. 2013, 46, 363-376. [CrossRef]

17. Evans, S.W.; Owens, J.S.; Wymbs, B.T.; Ray, A.R. Evidence-based psychosocial treatments for children and adolescents with attention deficit/hyperactivity disorder. J. Clin. Child Adolesc. Psychol. 2018, 47, 157-198. [CrossRef] [PubMed]

18. Dahl, V.; Ramakrishnan, A.; Spears, A.P.; Jorge, A.; Lu, J.; Bigio, N.A.; Chacko, A. Psychoeducation interventions for parents and teachers of children and adolescents with ADHD: A systematic review of the literature. J. Dev. Phys. Disabil. 2020, 32, $257-292$. [CrossRef]

19. Döpfner, M.; Ise, E.; Breuer, D.; Rademacher, C.; Metternich-Kaizman, T.W.; Schürmann, S. Long-term course after adaptive multimodal treatment for children with ADHD: An 8-year follow-up. J. Atten. Disord. 2020, 24, 145-162. [CrossRef] [PubMed]

20. Kos, J.; Richdale, A.L.; Hay, D.A. Children with Attention deficit Hyperactivity Disorder and their Teachers: A review of the literature. Int. J. Disabil. Dev. Educ. 2006, 53, 147-160. [CrossRef]

21. Jarque, S.; Tárraga, R.; Miranda, A. Conocimientos, concepciones erróneas y lagunas de los maestros sobre el trastorno por déficit de atención con hiperactividad. Psicothema 2007, 19, 585-590.

22. Ohan, J.L.; Cormier, N.; Hepp, S.L.; Visser, T.A.V.; Strain, M.C. Does Knowledge About Attention-Deficit/Hyperactivity Disorder Impact Teachers' Reported Behaviors and Perceptions? Sch. Psychol. Q. 2008, 23, 436-449. [CrossRef]

23. Sherman, J.; Rasmussen, C.; Baydala, L. The impact of teacher factors on achievement and behavioural outcomes of children with attention Deficit/ Hyperactivity disorder (ADHD): A review of the literature. Educ. Res. 2008, 50, 347-360. [CrossRef]

24. Sciutto, M.J.; Terjesen, M.D.; Kučerová, A.; Michalová, Z.; Schmiedeler, S.; Antonopoulou, K.; Shaker, N.Z.; Lee, J.-Y.; Alkahtani, K.; Drake, B.; et al. Cross-national comparisons of teachers' knowledge and misconceptions of ADHD. Int. Perspect. Psychol. 2016, 5, 34-50. [CrossRef]

25. Soroa, M.; Balluerka, N.; Gorostiaga, A. Development and validation of a questionnaire (the IRA-AGHN) to assess teachers' knowledge of Attention Deficit Hyperactivity Disorder. An. Psicol. 2014, 30, 1035-1043. [CrossRef]

26. Arnett, A.B.; MacDonald, B.; Pennington, B.F. Cognitive and behavioural indicators of ADHD symptoms prior to school age. J. Child Psychol. Psychiatry 2013, 54, 1284-1294. [CrossRef] [PubMed] 
27. Bekle, B. Knowledge and attitudes about Attention-Deficit Hyperactivity Disorder (ADHD): A comparison between practicing teachers and undergraduate education students. J. Atten. Disord. 2004, 7, 151-161. [CrossRef]

28. Anderson, D.L.; Watt, S.E.; Noble, W.; Shanley, D.C. Knowledge of Attention Deficit Hyperactivity Disorder (ADHD) and attitudes toward teaching children with ADHD: The role of teaching experience. Psychol. Sch. 2012, 49, 511-525. [CrossRef]

29. Rogers, M.; Tannock, R. Are Classrooms meeting the basic psychological needs of children with ADHD symptoms? A selfdetermination theory perspective. J. Atten. Disord. 2018, 22, 1354-1360. [CrossRef]

30. Toye, M.K.; Wilson, C.; Wardle, G.A. Education professionals' attitudes towards the inclusion of children with ADHD: The role of knowledge and stigma. J. Res. Spec. Educ. Needs 2019, 19, 184-196. [CrossRef]

31. Sciutto, M.J.; Terjesen, M.D.; Bender, A.S. Teachers' knowledge and misperceptions of Attention-Deficit/Hyperactivity Disorder. Psychol. Sch. 2000, 37, 115-122. [CrossRef]

32. Jarque, S.; Tárraga, R. Comparación de los conocimientos sobre el trastorno por déficit de atención con hiperactividad (TDAH) de los maestros en activo y los futuros educadores. Infanc. Aprendiz. 2009, 32, 517-529. [CrossRef]

33. Perold, M.; Louw, C.; Kleymhans, S. Primary school teachers' knowledge and misperceptions of attention deficit hyperactivity disorder (ADHD). S. Afr. J. Educ. 2010, 30, 457-473. [CrossRef]

34. Alkahtani, K.D.F. Teachers' Knowledge and Misconceptions of Attention Deficit/Hyperactivity Disorder. Psychology 2013, 4, 963-969. [CrossRef]

35. Anderson, D.L.; Watt, S.E.; Shanley, D.C. Ambivalent attitudes about teaching children with attention déficit hyperactivity disorder (ADHD). Emot. Behav. Difficulties 2017, 22, 332-349. [CrossRef]

36. Martinussen, R.; Tannock, R.; Chaban, P. Teachers' Reported Use of Instructional and Behavior Management Practices for Students with Behavior. Child Youth Care Forum 2011, 40, 143-210. [CrossRef]

37. Soroa, M.; Gorostiaga, A.; Balluerka, N. Conocimiento de los docentes sobre el TDAH: Relevancia de la formación y de las percepciones individuales. Rev. Psicodidáctica 2016, 21, 205-226. [CrossRef]

38. Strelow, A.E.; Dort, M.; Schwinger, M.; Christiansen, H. Influences on Teachers' Intention to Apply Classroom Management Strategies for Students with ADHD: A Model Analysis. Sustainability 2021, 13, 2558. [CrossRef]

39. Lawrence, K.; Estrada, R.D.; McCormick, J. Teachers' experiences with and perceptions of students with attention déficit/hyperactivity disorder. J. Pediatric Nurs. 2018, 36, 141-148. [CrossRef] [PubMed]

40. Snider, V.E.; Busch, T.; Arrowood, L. Teacher Knowledge of Stimulant Medication and ADHD. Remedial Spec. Educ. 2003, 24, 46-56. [CrossRef]

41. Ramos, N. Hispanic Teachers' Perceptions of Children with ADHD. Ph.D. Thesis, University of Texas Pan-American, Edinburgh, TX, USA, 2008.

42. Youssef, M.K.; Hutchinson, G.; Youssef, F.F. Knowledge of and Attitudes Toward ADHD among Teachers: Insights from a Caribbean Nation. SAGE Open 2015, 5, 1-8. [CrossRef]

43. Shroff, H.P.; Hardikar-Sawant, S.; Prabhudesai, A.D. Knowledge and misperceptions about Attention Deficit Hyperactivity Disorder (ADHD) among school teachers in Mumbai, India. Int. J. Disabil. Dev. Educ. 2017, 64, 514-525. [CrossRef]

44. Miranda Padilla, A.; Barrios Cuartas, D.; Duque Henao, L.F.; Burgos Arroyo, E.A.; Salazar Flórez, J.E. Knowledge About ADHD in Primary Teachers of Public Schools of Sabaneta, Antioquia. Rev. Colomb. Psiquiatr. 2018, 47, 165-169. [CrossRef] [PubMed]

45. Soriano-Ferrer, M.; Echegaray-Bengoa, J. Incidencia de la experiencia docente con el TDAH en los conocimientos, la autoeficacia y los niveles de estrés docente. Univ. Psychol. 2019, 18, 1-13. [CrossRef]

46. Stacey, M.A. Attention-Deficit/Hyperactivity Disorder: General Education Elementary School Teachers' Knowledge, Training, and Ratings of Acceptability of Interventions. Ph.D. Thesis, University of South Florida, Tampa, FL, USA, 2003.

47. Guerra, F.R. Teacher Knowledge of Attention Deficit Hyperactivity Disorder among Middle School Students in South Texas. Ph.D. Thesis, University of Texas, Austin, TX, USA, 2009. Available online: http://gradworks.umi.com/34/00/3400334.html (accessed on 8 April 2021).

48. Kos, J.M.; Richdale, A.L.; Jackson, M.S. Knowledge about Attention-Deficit/Hyperactivity Disorder: A comparison of in-service and preservice teachers. Psychol. Sch. 2004, 41, 517-526. [CrossRef]

49. Niznik, M.E. An Exploratory Study of the Implementation and Teacher outcomes of a Program to Train Elementary Educators about ADHD in the Schools. Ph.D. Thesis, University of Texas, Austin, TX, USA, 2004.

50. Jones, H.A.; Chronis-Tuscano, A. Efficacy of teacher in-service training for Attention-Deficit/Hyperactivity Disorder. Psychol. Sch. 2008, 45, 918-929. [CrossRef]

51. Syed, E.U.; Hussein, A.S. Increase in teachers' knowledge about ADHD Increase in teachers' Knowledge about ADHD after a week-long training program. J. Atten. Disord. 2010, 13, 420-423. [CrossRef] [PubMed]

52. Barnet, B.; Corkum, P.; Elik, N. A web-based intervention for elementary school teachers of students with attentiondeficit/hyperactivity disorder/ADHD). Psychol. Serv. 2012, 9, 227-230. [CrossRef]

53. Latouche, A.P.; Gascoigne, M. In-service training for increasing teachers' ADHD knowledge and self-efficacy. J. Atten. Disord. 2019, 23, 270-281. [CrossRef] [PubMed]

54. Campbell, D.T.; Stanley, J.C. Experimental and Quasi-Experimental Designs for Research; Ravenio Books: IL, USA, 2015.

55. Bryman, A. Social Research Methods; OUP Oxford: Oxford, UK, 2016.

56. Amado, L.; Jarque, S.; Ceccato, R. Differential impact of a multimodal versus pharmacological therapy on the core symptoms of attention deficit/hyperactivity disorder in childhood. Res. Dev. Disabil. 2016, 59, 93-104. [CrossRef] 
57. Miranda, A.; Presentación, M.J.; Gargallo, B.; Soriano, M.; Gil, M.D.; Jarque, S. El niño Hiperactivo (TDAH). Intervención en el aula. Un Programa de Formación Para Profesores; Servicio de Publicaciones de la Universidad Jaume I: Castellón, Spain, 1999.

58. Gargallo, B. Programa de Intervención Educativa Para Aumentar la Atención y la Reflexividad (PIAAR-R); TEA Ediciones: Madrid, Spain, 2000.

59. Lasisi, D.; Ani, C.; Lasebikan, V.; Sheikh, L.; Omigbodun, O. Effect of attention-deficit-hyperactivity-disorder training program on the knowledge and attitudes of primary school teachers in Kaduna, North West Nigeria. Child Adolesc. Psychiatry Ment. Health 2017, 11, 1-8. [CrossRef]

60. González Calleros, C.B. Modelo de diseño instruccional para el aprendizaje de matemáticas para estudiantes con TDAH. Ph.D. Thesis, Psychology Degree, Universidad Autónoma de Puebla, Puebla, Mexico, March 2021.

61. Bandura, A. Social Foundations of Thought and Action: A Social Cognitive Theory; Prentice-Hall: Englewood Cliffs, NJ, USA, 1986.

62. Reid, R.; Vasa, S.F.; Magg, J.W.; Wright, G. An Analysis of teachers perceptions of attention deficit disorder. J. Res. Dev. Educ. 1994, $27,193-202$.

63. Hinshaw, S.P.; Scheffler, R.M.; Fulton, B.D.; Aase, H.; Banaschewski, T.; Cheng, W.; Mattos, P.; Holte, A.; Levy, F.; Sadeh, A.; et al. International variation in treatment procedures for ADHD: Social context and recent trends. Psychiatr. Serv. 2011, 62, 459-464. [CrossRef]

64. Shehata, A.; Mahrous, E.; Farrag, E.; Hassan, Z. Effectiveness of structured teaching programme on knowledge, attitude, and management strategies among teachers of primary school toward children with attention deficit hyperactivity disorder. IOSR $J$. Nurs. Health Sci. 2016, 5, 29-37.

65. Park, S.J.; Park, W.J. Development and effects of an instructional coaching program regarding children with attention deficit hyperactivity disorder for elementary school teachers. J. Korean Acad. Nurs. 2017, 47, 305-318. [CrossRef] [PubMed]

66. Alabd, A.M.A.; Mesbah, S.K.; Alboliteeh, M. Effect of educational program on elementary school teachers' knowledge, attitude, and classroom management techniques regards attention deficit hyperactivity disorder. Int. J. Stud. Nurs. 2018, 3, 159-171. [CrossRef]

67. Khalil, A.I.; Alshareef, F.A.; Alshumrani, H.G. Knowledge, Attitude, and Behavioural Practice of Elementary Teacher of ADHD Children: Impact of an Educational Intervention. Am. J. Nurs. 2019, 8, 330-341. [CrossRef] 